\title{
Microbenthos, meiobenthos and fiddler crabs: trophic interactions in a tropical mangrove sediment
}

\author{
A. H. Dye \& T. A. Lasiak \\ Department of Zoology, University of Transkei, Private Bag X5092, Umtata, Transkei, Southern Africa
}

\begin{abstract}
Aspects of the feeding ecology of Uca vocans and Uca polita from tropical mangroves were studied. Gut analysis revealed that microheterotrophs were the major food source for both species although $U$. polita also ingested small numbers of microalgae. No evidence was found for the ingestion of meiobenthos. Based on measurements of feeding rate and mass of feeding pellets produced it is estimated that the $U$. vocans population forages $43 \%$ of the sediment surface during a low-tide feeding period of 2 to $2.5 \mathrm{~h}$. The corresponding figure for $U$. polita is $22 \%$. Abundance of meiobenthos increased 2 to 5 -fold when crabs were excluded from the sediment. It is suggested that avoidance by downward migration and/or competition for food resources may account for this difference.
\end{abstract}

\section{INTRODUCTION}

In marine sediments the benthic components involved in energy flow are the microbial community, the meiobenthos and the macro-deposit-feeders. Recently it has been shown that between 1 and $3 \%$ of both heterotrophic microbial and autotrophic standing stock is consumed by meiobenthos (Montagna 1984). Despite the considerable amount of information on the ecology of meiobenthos (Swedmark 1964, Jansson 1968, McIntyre 1969, Giere 1975, Ankar \& Elmgren 1976, Lasserre 1976) their precise role in benthic communities remains a matter for speculation (Gerlach 1971, 1978, Lee et al. 1974). Several studies have shown that meiobenthos constitute a food source for macro-deposit-feeders (Teal 1962, Braber \& De Groot 1973, Siebert et al. 1977, Bell \& Coull 1978).

Although it has long been suggested that bacteria may be an important food source for macrobenthos (Baier 1935, ZoBell \& Feltham 1942, Newell 1965, Odum \& De la Cruz 1967) there has been considerable debate concerning the relative importance of bacteria and detritus in the diet of deposit-feeders (Kirby-Smith 1975). Studies such as those of Newell (1965), Lopez et al. (1977) and Lopez \& Cheng (1983) provide evidence for the utilization of the microbial component rather than detritus per se. On the other hand the work of Teal (1962) and Adams \& Angelovic (1970) provides evidence to the contrary.
Despite the fact that fiddler crabs are dominant macro-deposit-feeders in many parts of the world little has been done to elucidate their interactions with the microbial community (Hoffman et al. 1984). The present study provides data on the relative contribution of various components of the sediment microbial community to the diet of Uca vocans (Latr.) and Uca polita (White) from tropical mangroves. Data on the response of the meiobenthos subsequent to the exclusion of crabs from the sediment are also presented.

\section{METHODS}

Study sites. The studies were carried out on a mudbank at the northern end of Bowling Green Bay close to the Australian Institute of Marine Science in Queensland $\left(19^{\circ} 15^{\prime} \mathrm{S}, 147^{\circ} 30^{\prime} \mathrm{E}\right)$. The substratum was characterized by a gradation from muddy sand at LWS to fine mud at HWS and supported a large population of fiddler crabs. Uca vocans predominated in the fine mud whereas $U$. polita was most abundant in the muddy sand. Both the sampling and caging experiments were carried out at approximately the mid-tide level along a $20 \mathrm{~m}$ stretch of the mud bank. Semidiurnal tides characterized the area and tidal amplitude was $1.5 \mathrm{~m}$.

Feeding studies. Crab feeding was studied by comparing unforaged sediment with both fresh feeding 
pellets and the gut contents of fed and starved crabs. Twenty $g$ of fresh feeding pellets were collected shortly after the start of a feeding session. After approximately 1 h of feeding activity the gut contents of 20 specimens were removed and preserved in $5 \%$ formol-saline. At the same time 7 specimens of each species were brought back to the laboratory and kept in $0.45 \mu \mathrm{m}$ filtered sea water without access to food for $48 \mathrm{~h}$. The water was changed twice during the starvation period.

Meiofauna were counted on $20 \times 1 \mathrm{~g}$ samples of sediment and feeding pellets after each sample was stained with $1 \mathrm{ml} 0.5 \%$ Rose Bengal. In each case the entire sample was stained and counted under a dissecting microscope. Bacteria, Protozoa and algae were determined on similar samples after first homogenizing the sediment in a Sorval homogenizer at 16000 rpm with $50 \mathrm{ml}$ of filtered sea water $(0.45 \mu \mathrm{m})$ as described by Dye (1979, 1983). Extracted samples were stained with Acridine Orange and counted by epifluorescence microscopy (Daley \& Hobbie 1975).

The feeding intensity of the crabs was determined from observations of 30 specimens of each species over $60 \mathrm{~s}$ periods. Since the actual feeding motions were too rapid for accurate counting, the number of feeding pellets produced per min was noted. The mass of the pellets was determined after approximately 500 had been collected from each species and oven-dried.

Caging experiments. The fact that $U_{C a}$ vocans and $U$. polita tended to occur on different substrata made it possible to study these species separately. In order to fit between existing burrows the exclusion cages had to be smaller than the control cages and were constructed from $10 \mathrm{~cm}$ lengths of PVC pipe $20 \mathrm{~cm}$ in diameter, to which a $20 \mathrm{~cm}$ high sleeve of $10 \mathrm{~mm}$ steel mesh was fitted. Two such cages were sunk so that only the mesh protruded above the substratum. A $5 \mathrm{~cm}$ high strip of $1 \mathrm{~mm}$ plastic mesh was wrapped around the side to exclude other macro-deposit-feeders.
As controls, 3 square $0.25 \mathrm{~m}^{2}$ cages were used to enclose 4 to 6 crabs and their established burrows. The cages consisted of a $10 \mathrm{~cm}$ high skirt of sheet steel topped with an equal height of $10 \mathrm{~mm}$ steel mesh, which was also used for the roof of the cage. Again the assembly was sunk to mesh depth and a $5 \mathrm{~cm}$ high strip of $1 \mathrm{~mm}$ plastic mesh was wrapped around the sides.

The cages were left in position for $14 \mathrm{~d}$. At the start 3 sets of $10 \times 1.6 \mathrm{~cm}^{2}$ cores were taken from each control cage and 3 sets of 5 cores were taken from the exclusion cages. Samples were taken with a modified $10 \mathrm{ml}$ plastic syringe. Only the top 1 to $2 \mathrm{~mm}$ of sediment was retained, its fluid nature making it difficult to be more precise. The procedure was repeated at the end of the experiment.

\section{RESULTS}

\section{Feeding}

Feeding pellets from Uca vocans contained $31 \%$ less bacteria than the sediment but did not differ from sediment in respect of microalgal content (Table 1). The guts of freshly fed $U$. vocans contained bacteria and detritus but no trace of algae could be found. There was also no significant difference in the density of Protozoa between feeding pellets and fresh sediment (t-test, $\mathrm{p}<0.05$ ) although Protozoa were found in the gut. There was a significantly lower density of meiofauna in the feeding pellets compared with sediment (t-test, $\mathrm{p}<0.05$ ) but no trace of meiofaunal remains was ever found in guts. Although small amounts of sediment were found in the guts of starved crabs residual populations of bacteria and Protozoa were small (Table 1).

Uca polita feeding pellets had less bacteria, Protozoa and algae than the fresh sediment (Table 1). There was a small residual population of bacteria present after

Table 1. Uca vocans and $U$. polita. Comparison of unforaged sediment with the feeding pellets and gut contents of fed and starved fiddler crabs. Sed: sediment; FP: feeding pellet; Stvd: Starved

\begin{tabular}{|c|c|c|c|c|c|c|c|c|}
\hline \multirow{2}{*}{$\begin{array}{l}\text { Organism } \\
\mathrm{N}\end{array}$} & \multicolumn{4}{|c|}{ Uca vocans } & \multicolumn{4}{|c|}{ Uca polita } \\
\hline & $\begin{array}{c}\text { Sed } \\
20\end{array}$ & $\begin{array}{l}\text { FP } \\
20\end{array}$ & $\begin{array}{c}\text { Fed } \\
20\end{array}$ & $\begin{array}{l}\text { Stvd } \\
7\end{array}$ & $\begin{array}{c}\text { Sed } \\
20\end{array}$ & $\begin{array}{l}\text { FP } \\
20\end{array}$ & $\begin{array}{c}\text { Fed } \\
20\end{array}$ & $\begin{array}{c}\text { Stvd } \\
7\end{array}$ \\
\hline $\begin{array}{l}\text { Bacteria } \\
\mathrm{N} \times 10^{9} \mathrm{~g}^{-1} \pm \mathrm{SD}\end{array}$ & $\begin{array}{r}2.46 \\
\pm 0.18\end{array}$ & $\begin{array}{r}1.69 \\
\pm 0.23\end{array}$ & $\begin{array}{r}1.47 \\
\pm 0.79\end{array}$ & $\begin{array}{r}0.68 \\
\pm 0.36\end{array}$ & $\begin{array}{r}2.33 \\
\pm 0.28\end{array}$ & $\begin{array}{r}1.29 \\
\pm 0.63\end{array}$ & $\begin{array}{r}0.72 \\
\pm 0.49\end{array}$ & $\begin{array}{r}0.06 \\
\pm 0.06\end{array}$ \\
\hline $\begin{array}{l}\text { Algae } \\
\mathrm{N} \times 10^{6} \mathrm{~g}^{-1} \pm \mathrm{SD}\end{array}$ & $\begin{array}{r}6.57 \\
+3.68\end{array}$ & $\begin{array}{r}6.00 \\
\pm 3.95\end{array}$ & 0.00 & 0.00 & $\begin{array}{r}4.60 \\
\pm 2.14\end{array}$ & $\begin{array}{r}3.37 \\
\pm 1.54\end{array}$ & $\begin{array}{r}0.26 \\
\pm 0.07\end{array}$ & 0.00 \\
\hline $\begin{array}{l}\text { Protozoa } \\
\mathrm{N} \times 10^{7} \mathrm{~g}^{-1} \pm \mathrm{SD}\end{array}$ & $\begin{array}{r}3.60 \\
\pm 1.90\end{array}$ & $\begin{array}{r}4.27 \\
\pm 0.13\end{array}$ & $\begin{array}{r}1.23 \\
\pm 0.16\end{array}$ & $\begin{array}{r}0.46 \\
+0.06\end{array}$ & $\begin{array}{r}2.10 \\
\pm 0.25\end{array}$ & $\begin{array}{r}1.35 \\
\pm 0.60\end{array}$ & $\begin{array}{r}0.58 \\
\pm 0.26\end{array}$ & 0.00 \\
\hline $\begin{array}{l}\text { Meiofauna } \\
\mathrm{Ng}^{-1} \pm \mathrm{SD}\end{array}$ & $\begin{array}{r}183 \\
\pm \quad 31\end{array}$ & $\begin{array}{r}63 \\
\pm 21\end{array}$ & & & $\begin{array}{r}191 \\
\pm \quad 50\end{array}$ & $\begin{array}{r}59 \\
\pm 32\end{array}$ & 0 & 0 \\
\hline
\end{tabular}


starvation. Table 1 shows that there was some ingestion of microalgae but the number found in the gut was low compared with that found in sediment. There was a significant decrease in meiofaunal density ( $t$-test, $\mathrm{p}<$ 0.05) in feeding pellets compared with sediment but there were no meiofaunal remains in the gut.

Although more than $4 \mathrm{~h}$ was available for feeding during low tide, crabs of both species spent only 2.5 to $3 \mathrm{~h}$ actually ingesting material. Females emerged about an hour before males and retreated into their burrows about $1 \mathrm{~h}$ ahead of the males. The larger crab, Uca vocans (carapace width $20.46 \pm 0.97 \mathrm{~mm}$ ), produced feeding pellets at a rate of $8.6 \pm 0.46 \mathrm{~min}^{-1}$ each weighing $37.5 \pm 6.0 \mathrm{mg}$ dry. Based on an observed foraging depth of $1.0 \mathrm{~mm}$ this represents a foraged area of $214 \pm 20 \mathrm{~cm}^{2}$ per feeding session $(2.5 \mathrm{~h})$. U. polita (carapace width $14.66 \pm 0.88 \mathrm{~mm}$ ) produced $19.3 \pm 1.3$ feeding pellets $\mathrm{min}^{-1}$, each with a dry mass of of $7.5 \pm$ $0.5 \mathrm{mg}$. This represents a foraged area of $108.0 \pm 9.5$ $\mathrm{cm}^{2}$ per feeding session. At a density of $20 \pm 5$ crabs per $\mathrm{m}^{2} U$. vocans may forage $43 \pm 4 \%$ and $U$. polita may forage $22 \pm 2 \%$ of the mud surface. No significant differences in the rate at which feeding pellets are produced were found between the sexes of either species ( $t$-test, $p<0.05$ ) and there was no evidence of coprophagy.

Meiobenthos was present in the surface sediment at a density of $41 \pm 11$ animals $\mathrm{cm}^{-2}$ and was numerically dominated by nematodes $(98 \%)$. When crabs were excluded from the sediment the density of meiobenthos increased 5-fold in the Uca vocans area and up to 3 -fold in the area occupied by $U$. polita (Fig. 1). These increases were highly significant (t-test, $\mathrm{p}<0.001$ ).

\section{DISCUSSION}

The present study indicates that bacteria, and to a lesser extent Protozoa, are important food sources for both $U_{C a}$ vocans and $U$. polita. Although both species had detrital particles in their guts it is not known to what extent, if any, this material is assimilated. The fact that detrital material was present after $48 \mathrm{~h}$ of starvation is consistent with the conclusions of several studies that deposit-feeders assimilate mainly the microbial component of the ingested material (Newell 1965, Hargrave 1971, Lopez et al. 1977).

Neither species appears to ingest large amounts of microalgae despite the fact that the surface of the sediment was often obviously green and preliminary observations on surface scrapes indicated considerable numbers of large pennate diatoms as well as nematodes. It is suggested that the flotation feeding mechanism (Miller 1961) eliminates large particles, among which are the majority of microalgae and meiobenthos. This agrees with the findings of Robertson \& Newell (1982) on the particle selection ability of various $U_{c a}$ species. The large discrepency between the density of meiobenthos in fresh sediment and in feeding pellets may stem from a difference in sampling. The fluid nature of the sediment and the frequent presence of small grit particles made it difficult to ensure that only the upper $1 \mathrm{~mm}$ was retained from every core. Since Uca spp. forage mainly the upper 1 $\mathrm{mm}$ the density of meiofauna available may be somewhat lower than indicated although nematodes are still abundant.

The increase in abundance of meiofauna in the

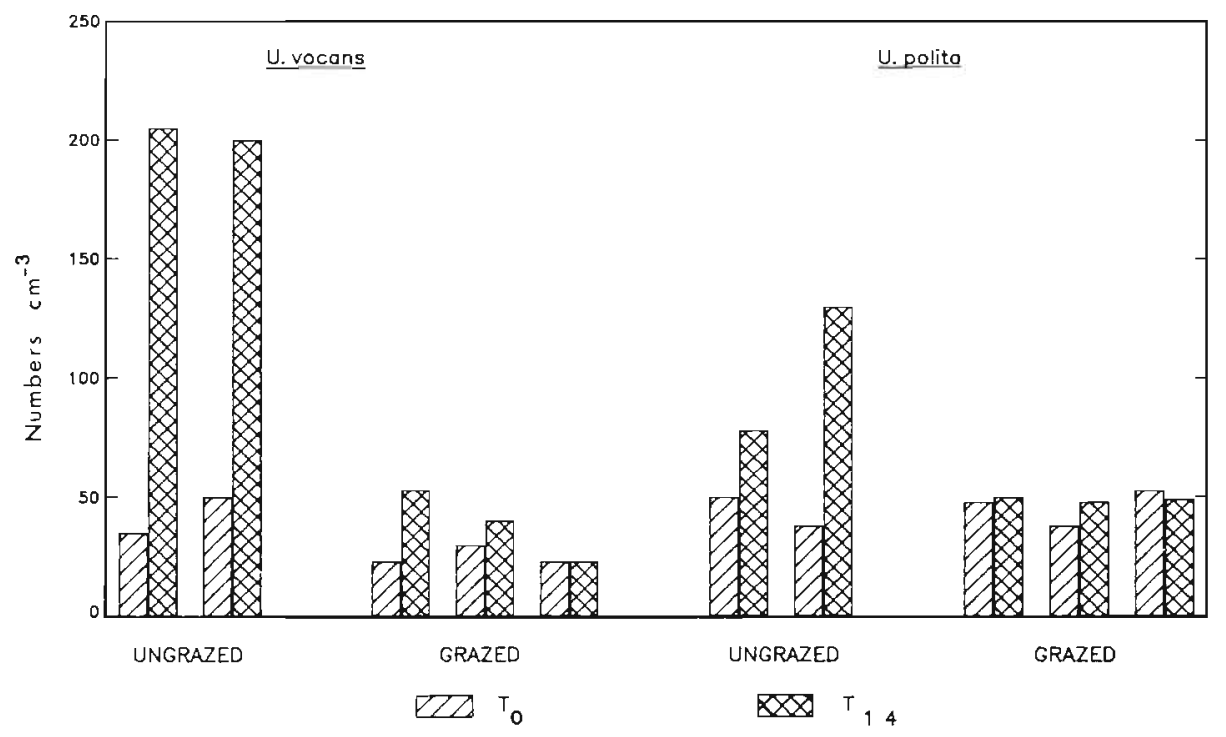

Fig. 1. Effect of fiddler crab exclusion on the abundance of meiobenthos in surface sediments. Ungrazed $N=15(\times 2)$, grazed $\mathrm{N}=30(\times 3) . \mathrm{T}_{0}$ : start of experiment; $\mathrm{T}_{14}$ : after $14 \mathrm{~d}$ exclusion 
exclusion cages may arise in a number of ways: by passive deposition due to tidal currents, by growth and reproduction leading to an increase in biomass, or by upward migration from deeper layers. Tidal suspension and transport of meiofauna has been reported by a number of workers. Although various mechanisms have been proposed, the work of Hagerman \& Rieger (1981), Siebert (1981) and Palmer \& Gust (1985) supports the idea of passive transport resulting from mechanical scouring. This process could presumably be enhanced by mechanical disturbance of sediment such as is caused by Uca spp. Any mechanical obstruction such as a cage will affect the flow characteristics of water close to the sediment surface and thus influence the processes of suspension and deposition. No significant differences in the abundance of meiofauna were detected in the grazed cages over the $14 \mathrm{~d}$ period (t-test, $\mathrm{p}<0.05$ ) and the effect appears to be minimal in this case. No obvious deposition of material was seen in the exclusion cages and it is difficult to estimate to what extent, if any, passive deposition contributed to the increase in meiofaunal abundance Palmer \& Gust (1985) found a maximum of $0.7 \%$ of sediment meiofauna suspended in the water column and their mean was considerably lower than this. It seems unlikely that deposition alone could account for the substantial increase in meiofaunal abundance reported here.

Estimates of meiofaunal productivity indicate a turnover of between 5 and $10 \mathrm{yr}^{-1}$ depending on conditions (McIntyre 1969, Gerlach 1971, Arlt 1973). The duration of the present experiment was only $14 \mathrm{~d}$. At the higher turnover this means an increase of about $40 \%$ which is far short of the actual observed increase. This also does not take into account mortality during the experimental period.

Vertical migration of meiofauna is well documented, particularly in sandy areas, and is usually associated with desiccation (Renaud-Debyser 1963, Boaden 1968, Harris 1972, McLachlan et al. 1977, Dye 1978). The decrease in stability of the surface sediments caused by Uca spp. may force the meiofauna to migrate downwards. When this effect is removed, as in the exclusion cages, meiofauna return to the surface once again. There may even be a cyclic migration of meiofauna tuned to the faraging activity of the crabs.

From the number and mass of pellets produced it is evident that these crabs can process a significant area of substratum during a low tide period. Although the crabs feed only during diurnal low tide (Salmon 1984) there are several days a month when low tide occurs twice during daylight. With the possible ingestion of up to $30 \%$ of the standing stock of bacteria it can be expected that foraging by fiddler crabs will have a significant effect on edaphic microbial populations.
In a study of the grazing effects of the gastropod Nassarius obsoletus, Pace et al. (1979) found a significant decrease in sediment ATP after $12 \mathrm{~d}$ of grazing, when compared with ungrazed plots. Connor \& Teal (1982) found that intense grazing by Ilyanassa obsoleta reduced algal standing stock and depressed photosynthesis and respiration. Although a considerable amount is known about the feeding mechanisms and behaviour of fiddler crabs there is little information on their effect on the sediment microbial community. A recent study by Hoffman et al. (1984) on the effects of foraging by $U_{C a}$ pugnax on meiofauna yielded similar results to those of the present study. An order of magnitude increase in the abundance of nematodes in surface sediments accompanied total removal of crabs and partial removal resulted in almost a doubling of meiofauna density. While these data clearly indicate that the presence of fiddler crabs in some way depresses meiofaunal abundance there is little evidence in favour of predation. Hoffman et al. (1984) do not present data on gut contents and the possibility that the effect is secondary cannot be discounted. If fiddler crabs and meiofauna were, for example, competing for the same food resource (detritus/bacteria) then the removal of the crabs should favour meiofauna and result in an increase in its abundance. Further study is required to resolve the relative importance of avoidance and competition in this regard.

As noted by Tenore (1983) the relative importance of microbes in the nutrition of deposit-feeders depends on the quality of carbon and nitrogen sources in the sediment. For example seaweed detritus and diatoms may be consumed directly while more refractory material such as mangrove and salt marsh detritus requires conversion to microbial carbon and nitrogen prior to ingestion. In the present case most of the diatoms appear to be excluded by the feeding mechanism. The major source of organic material is mangrove detritus and hence microbes can be expected to constitute an important source of nutrition for fiddler crabs.

Whether bacteria alone can satisfy the nutritional requirements of deposit-feeder is open to question. Tunnicliffe \& Risk (1977) concluded that low microbial production forces the deposit-feeding bivalve Macoma balthica to switch to suspension feeding when submerged, to supplement its diet. Little is known about the nutritional requirements of tropical fiddler crabs but Hargrave (1971) has estimated that ingestion of $10 \%$ of the daily microbial production is sufficient to meet the food requirements of the amphipod Hyallela azteca. Microbial production is usually high in tropical sediments and, as suggested by Newell \& Field (1983) for benthic communities, ingestion of a relatively small proportion of this production may well be sufficient for consumers. 
Acknowledgements. The authors are indebted to the Council for Scientific and Industrial Research (South Africa) and the University of Transkei for their financial assistance. The Australian Institute of Marine Science is thanked for its considerable material assistance. Dr. A. Robertson is thanked for constructive comments during the course of the work, and Dr W. Emmerson for commenting on the manuscript.

\section{LITERATURE CITED}

Ankar, S., Elmgren, R. (1976). The benthic macro- and meiofauna of the Askö-Landsort area (Northern Baltic proper). A stratified sampling survey. Contr. No. 11, Askö Lab., Univ. Stockholm, Sweden

Arlt, G. (1973). Zur produktionsbiologischen Bedeutung der Meiofauna in Küstengewässern. Wiss. Z. Univ. Rostock 22: $1141-1145$

Baier, C. R. (1935). Studien zur Hydrobakteriologie stehender Binnengewässer. Arch. Hydrobiol. 29: 183-264

Bell, S. S., Coull, B. C. (1978). Field evidence that shrimp predation regulates meiofauna. Oecologia (Berl.) 35: $141-148$

Boaden, P. J. S. (1968). Water movement - a dominant factor in intertidal ecology. Sarsia 34: 125-136.

Braber, L., De Groot, S. J. (1973). The food of five flatfish species (Pleuronectiformes) in the southern North Sea. Neth. J. Sea Res. 6: 163-172

Connor, M. S., Teal, J. M. (1982). The effect of feeding by mud snails, Ilyanassa obsoleta (Say), on the structure and metabolism of a laboratory benthic algal community. J. exp. Mar Biol. Ecol. 65: 29-45

Daley, R. J., Hobbie, J. E. (1975). Direct counts of aquatic bacteria by a modified epifluorescence technique. Limnol. Oceanogr. 20: 875-883

Dye, A. H. (1978). Diurnal vertical migrations of meiofauna in an estuarine sand flat. Zool. Afr 13: 201-205

Dye, A. H. (1979). Quantitative estimation of protozoa from sandy substrates. Estuar. coast. mar. Sci. 8: 199-204

Dye, A. H. (1983). A method for the quantitative enumeration of bacteria from estuarine sediments. Estuar. coast. Shelf Sci. $17 \cdot 207-212$

Gerlach, S. A. (1971). On the importance of marine meiofauna for benthos communities. Oecologia (Berl.) 6: 176-190

Gerlach, S. A. (1978). Food-chain relationship in subtidal silty mud sediments and the role of mejofauna in stimulating bacterial productivity. Oecologia (Berl.) 33: 55-69

Giere, O. (1975). Population structure, food relations and ecological role of marine oligochaetes, with special reference to meiobenthic species. Mar. Biol. 31: 139-156

Hagerman, G. M., Rieger, R. M. (1981). Dispersal of benthic meiofauna by wave and current action in Bogue Sound, North Carolina, U.S.A. P.S.Z.N. Mar Ecol. 2: 245-270

Hargrave, B. T. (1971). An energy budget for a depositfeeding amphipod. Limnol. Oceanogr. 16: 99-103

Harris, R. P. (1972). The distribution and ecology of interstitial meiofauna in a sandy beach at Whitstable Bay, east Cornwall. J. mar. biol. Ass. U.K. 52: 1-18

Hoffman, J. A., Katz, J., Bertness, M. D. (1984). Fiddler crab deposit-feeding and meiofauna abundance in salt marsh habitats. J. exp. mar. Biol. Ecol. 82: 161-174

Jansson, B. (1968). Quantitative and experimental studies of the interstitial fauna in four Swedish sandy beaches. Ophelia 5: 1-71

Kirby-Smith, W. (1975). The detritus problem and the feeding and digestion of an estuarine organism. In: Wiley, M. (ed.) Estuarine processes; uses, stresses and adaptations to the estuary. Estuarine Research Conference Proceedings, Galveston, Texas, USA., p 469-479

Lasserre, P. (1976). Metabolic activities of benthic microfauna and meiofauna. Recent advances and review of suitable methods of analysis. In: McCave, I. N. (ed.) The benthic boundary layer. Plenum Press, New York, p. 95-142

Lee, J. J., Tenore, K., Tietjen, J. H., Mastropaolo, C. (1974). An experimental approach towards understanding the role of meiofauna in a detritus-based marine food web. Biol. Bull. mar. biol. Lab., Woods Hole 147: 488-489

Lopez, G. R., Cheng, I.-J. (1983) Synoptic measurements of ingestion rate, ingestion selectivity and absorption efficiency of natural foods in the deposit-feeding molluscs Nucula annulata (Bivalvia) and Hydrobia totteni (Gastropoda). Mar Ecol. Prog. Ser 11: 55-62

Lopez, G. R., Levinton, J. S., Slobodkin, L. B. (1977). The effect of grazing by the detritivore Orchestia grillus on Spartina litter and its associated microbial community. Oecologia (Berl.) 30; 111-127

McIntyre, A. D. (1969). Ecology of marine meiobenthos. Biol. Rev, 44: 245-290

McLachlan, A., Erasmus, T., Furstenberg, J. P. (1977). Migrations of sandy beach meiofauna. Zool. Afr. 12: 254-277

Miller, D. C. (1961). The feeding mechanism of fiddler crabs, with ecological considerations of teeding adaptations. Zoologica, N. Y. 46: 89-101

Montagna, P. A. (1984). In situ measurement of meiobenthis grazing rates on sediment bacteria and edaphic diatoms. Mar Ecol. Prog. Ser. 18: 119-130

Newell, R. C. (1965). Detritus in the nutrition of marine molluscs. Proc zool. Soc. Lond. 144: 25-45

Newell, R. C., Field, J. G. (1983). The contribution of bacteria and detritus to carbon and nitrogen flow in a benthic community. Mar Biol. Lett. 4: 23-36

Odum, E. P., De La Cruz, A. A. (1967). Particulate organic detritus in a Georgia salt marsh estuarine ecosystem. In: Lauff, G. H. (ed.) Estuaries. Publ. Am. Ass. Advmt. Sci. 83: 383-388

Pace, M. L., Schimmel, S., Darley, W. M. (1979). The effect of grazing by a gastropod, Nassarius obsoletus, on the benthic microbial community of a salt marsh mud flat. Estuar. coast. mar. Sci. 9: 121-134

Palmer, M. A., Gust, G. (1985). Dispersal of meiofauna in a turbulent tidal creek. J mar Res. 43: 179-210

Renaud-Debyser, J. (1963). Recherches ecologiques sur la faune interstitielle des sable Bassin d'Aracachon, ile de Bimini, Bahamas. Vie Milieu Suppl. T14: 463-550

Robertson, J. R., Newell, S. Y (1982). A study of particle ingestion by three fiddler crab species foraging on sandy sediments. J. exp. mar. Biol. Ecol. 65: 11-17

Salmon, M. (1984). The courtship, aggression and mating system of a primitive fiddler crab. Uca vocans (Ocypodidael. Trans. zool. Soc. Lond. 37: 1-50

Siebert, J. R. (1981). Intertidal hyperbenthic populations in the Nanaimo Estuary. Mar. Biol. 64: 259-265

Siebert, J., Brown, T. J., Healy, M. C., Kask, B. A., Naiman, R. J. (1977). Detritus-based food webs: exploitation by juvenile chum salmon (Onchorhynchus keta). Science 649-650

Swedmark, B. (1964). The interstitial fauna of marine sand. Biol. Rev. 39: 1-47

Teal, J. M. (1962). Energy flow in the salt marsh ecosystem of Georgia. Ecology 43: 614-624

Tenore, K. R. (1983). Organic nitrogen and caloric content of detritus III. Effect on growth of a deposit-feeding polychaete, Capitella capitata. Estuar. coast. Shelf Sci. 17: 733-742 
Tunnicliffe, V., Risk, M. J. (1977). Relationship between the bivalve Macoma balthica and bacteria in intertidal sediments: Minas Bay, Bay of Fundy. J. mar. Res. 35: 499-507
ZoBell, C. E., Feltham, C. B, (1942). The bacterial flora of a marine mud flat as an ecological factor. Ecology 23: 69-77

This article was presented by Dr. J. S. Bunt; it was accepted for printing on June 30, 1986 